\title{
Users' preferences with an internet-based system for self-monitoring of blood glucose: a 5-year experience
}

\section{György Jermendy ${ }^{1}$, Ágnes Kecskés², Attila Nagy², Tamás Ági², György Bibok²}

${ }^{1}$ Bajcsy-Zsilinszky Hospital, Medical Department, Budapest, Hungary; ${ }^{277}$ Elektronika Ltd, Budapest, Hungary

e-mail: gyjermendy@mail.datanet.hu

\section{BACKGROUND AND AIMS}

Internet-based disease management has become popular especially among patients with chronic conditions such as diabetes.

In 2010, a nationwide internet-based telecommunication system was introduced in Hungary for improving the care of patients with self-monitoring of blood glucose (SMBG).

Diabetic patients with particular glucometers $\left(\right.$ Dcont $\left.^{\circledR}\right)$ have the possibilities to upload the results of SMBG via internet-based telecommunication system.

After automatic uploading of the SMBG results, different statistics, graphics and tendencies over time become immediately available for the patients to review and to share with health care providers.

The aim of the study was to analyze the 5-year experiences (2010-2015) with this internet-based telecommunication system

\section{PATIENTS AND METHODS}

Data of regular users were analyzed (regular users: patients with $>10$ blood glucose values)

A total of 2,532,004 blood glucose values were uploaded by 2,535 regular users (775 women with 813,479 and 1,760 men with $1,718,525$ blood glucose values) (Table 1 )

Statistical analysis was performed anonymously. Age, gender, diabetes duration, type of diabetes and mode of treatment were registered only.

Table 1. Number of regular users and uploaded blood glucose

\begin{tabular}{|l|c|c|c|}
\hline values & $\begin{array}{c}\text { Regular users } \\
(\mathbf{n})\end{array}$ & $\begin{array}{c}\text { Uploaded blood } \\
\text { glucose values } \\
(\mathbf{n})\end{array}$ & $\begin{array}{c}\text { Blood glucose } \\
\text { values/user } \\
(\mathbf{n})\end{array}$ \\
\hline Women & 775 & 813,479 & 1,050 \\
\hline Men & 1,760 & $1,718,525$ & 976 \\
\hline Total & 2,535 & $2,532,004$ & 999 \\
\hline
\end{tabular}

\section{RESULTS}

The age of patients varied from 2 to 91 years (men: $45.9 \pm 18.7$, women $39.1 \pm 20.6$ years). A bimodal distribution of age was noted in users with type 1 diabetes with two peaks at the age range of 10-19 and 35-40 years. Users with type 2 diabetes were older with a peak age range of 55-65 years (Figure 1, Figure 2)

The median value of blood glucose was 7.6 (IQR 5.6 - 10.6) $\mathrm{mmol} / \mathrm{L}$; women 7.8 (IQR 5.6 - 11.1) mmol/L, men: 7.5 (IQR $5.6-10.4) \mathrm{mmol} / \mathrm{L} ; \mathrm{p}<0.05$. (Table 2, Figure 3).

Table 2. Values of self-monitoring of blood glucose (SMBG)

\begin{tabular}{|l|r|c|c|c|}
\hline \multirow{2}{*}{} & \multirow{2}{*}{$\begin{array}{c}\text { Uploaded values } \\
\text { (n) }\end{array}$} & \multicolumn{3}{|c|}{$\begin{array}{c}\text { Interquartile range } \\
\text { (mmol//) }\end{array}$} \\
\cline { 3 - 5 } & & $\mathbf{2 5 \%}$ & $\mathbf{5 0 \%}$ (median) & $\mathbf{7 5 \%}$ \\
\hline Women & 813,479 & 5.6 & 7.8 & 11.1 \\
\hline Men & $1,718,525$ & 5.6 & $7.5 *$ & 10.4 \\
\hline Total & $2,532,004$ & 5.6 & 7.6 & 10.6 \\
\hline
\end{tabular}

${ }^{*} \mathrm{p}<0.05$ versus women

Regular users with type 1 diabetes $(n=1,272 ; 50.2 \%)$ predominated over users with type $2(n=1,011$; $39.9 \%)$. The majority of users $(n=1,563 ; 61.6 \%)$ were treated with insulin only, whereas 354 patients $(13.9 \%)$ were on insulin plus oral drugs (Table 3 ).

Only a subset of patients $(n=291,11.5 \%)$ reported fasting or pre-meal blood glucose values together with immediate postprandial (90-120 min) measurements.

At least one blood glucose value within hypoglycemic range $(\leq 3.9 \mathrm{mmol} / \mathrm{L})$ was registered in $80.9 \%$ of patients (Table 4 )

\section{CONCLUSIONS}

The internet-based telecommunication is a highly popular and valuable tool for patients with diabetes across all age groups.

Improvement in information technology (synchronous or asynchronous teleconsultation or extension to mobile phones) hold the promise for enhanced education, patient support and ultimately better diabetes control.

Figure 1. Distribution of regular users $(n=2,535)$ according to the type of diabetes and age

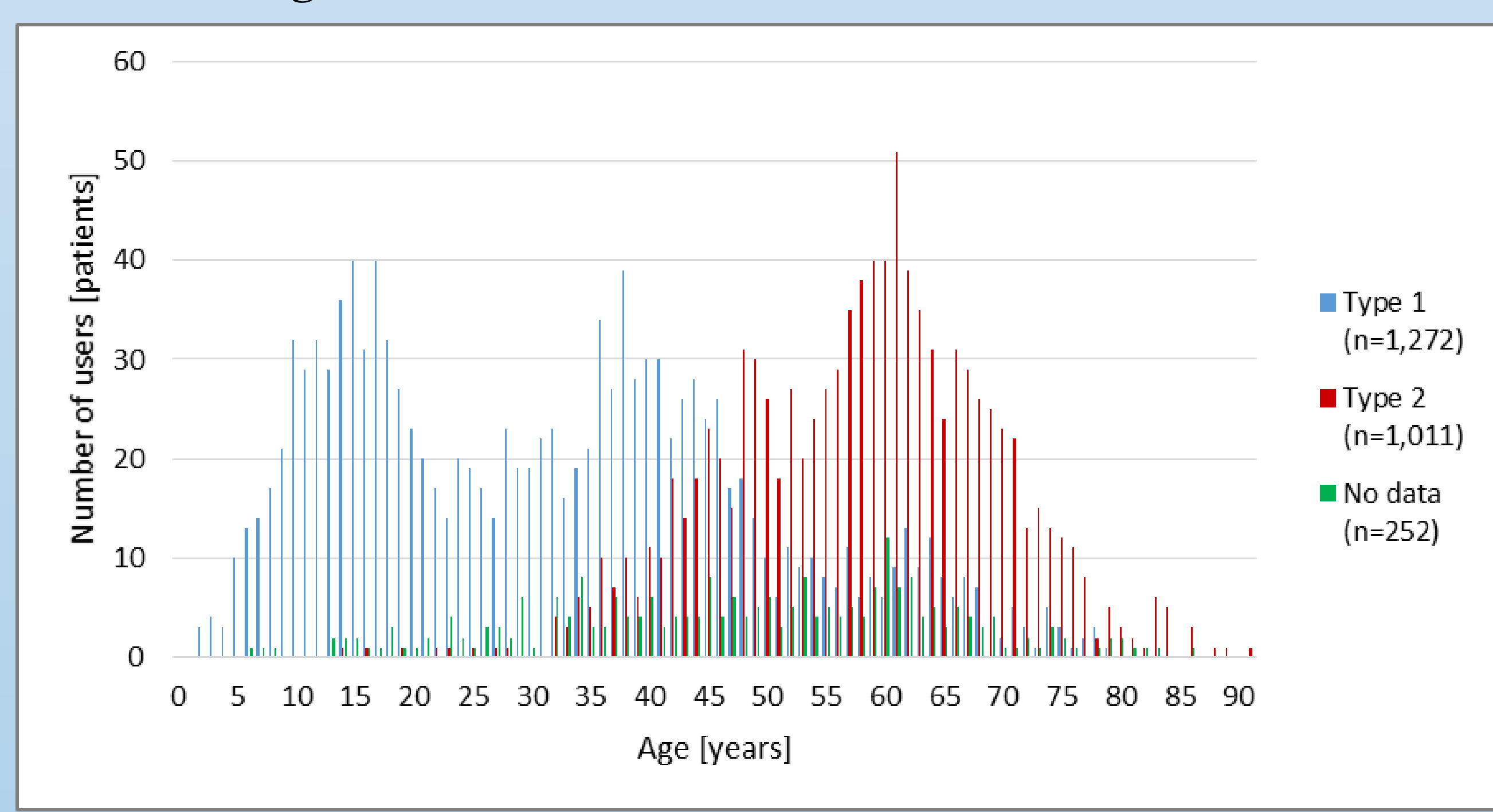

Figure 2. Age and gender distribution of regular users $(n=2,535)$

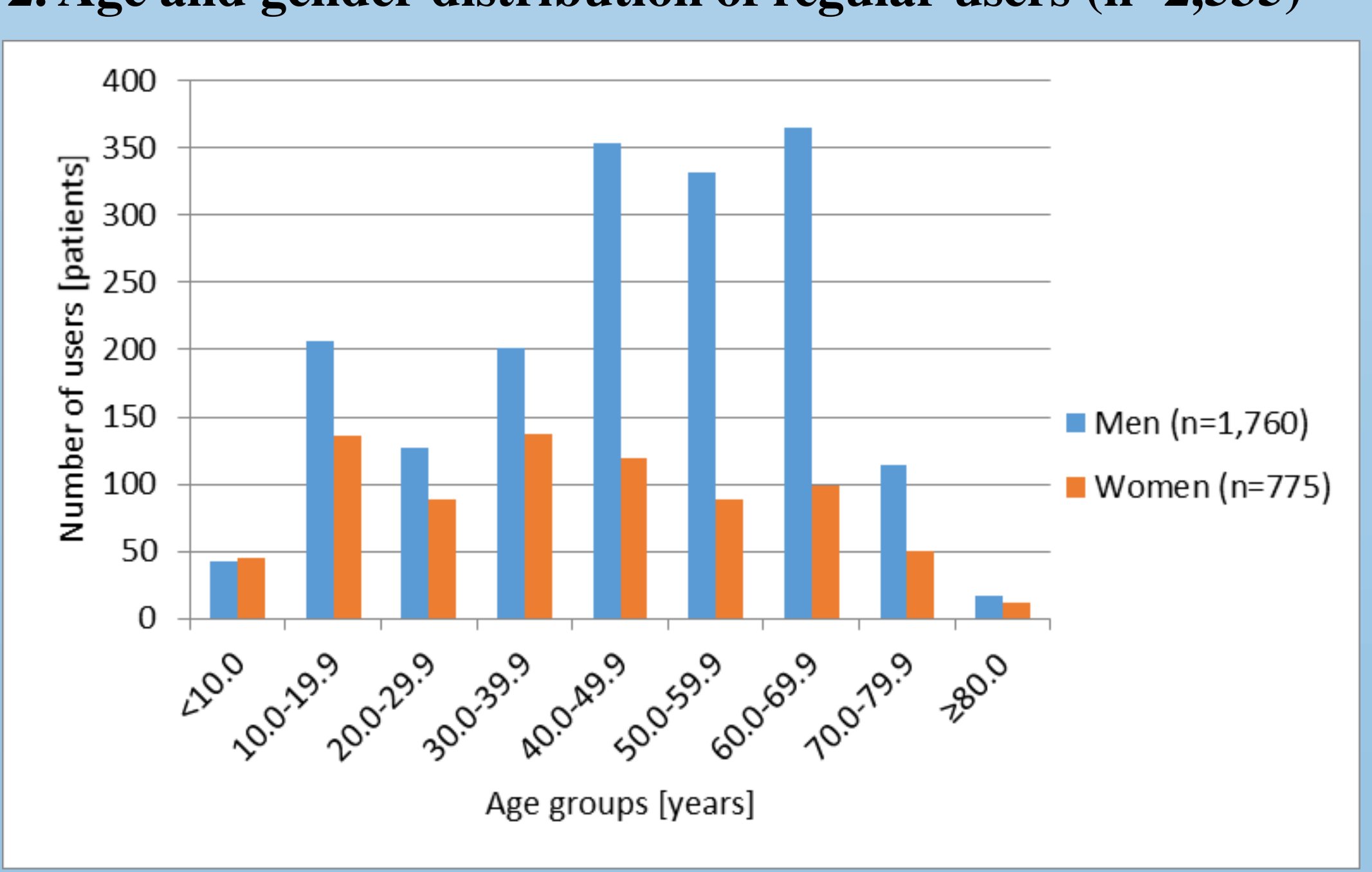

Figure 3. Values of SMBG in men $(n=1,718,525)$ and women $(n=813,479)$

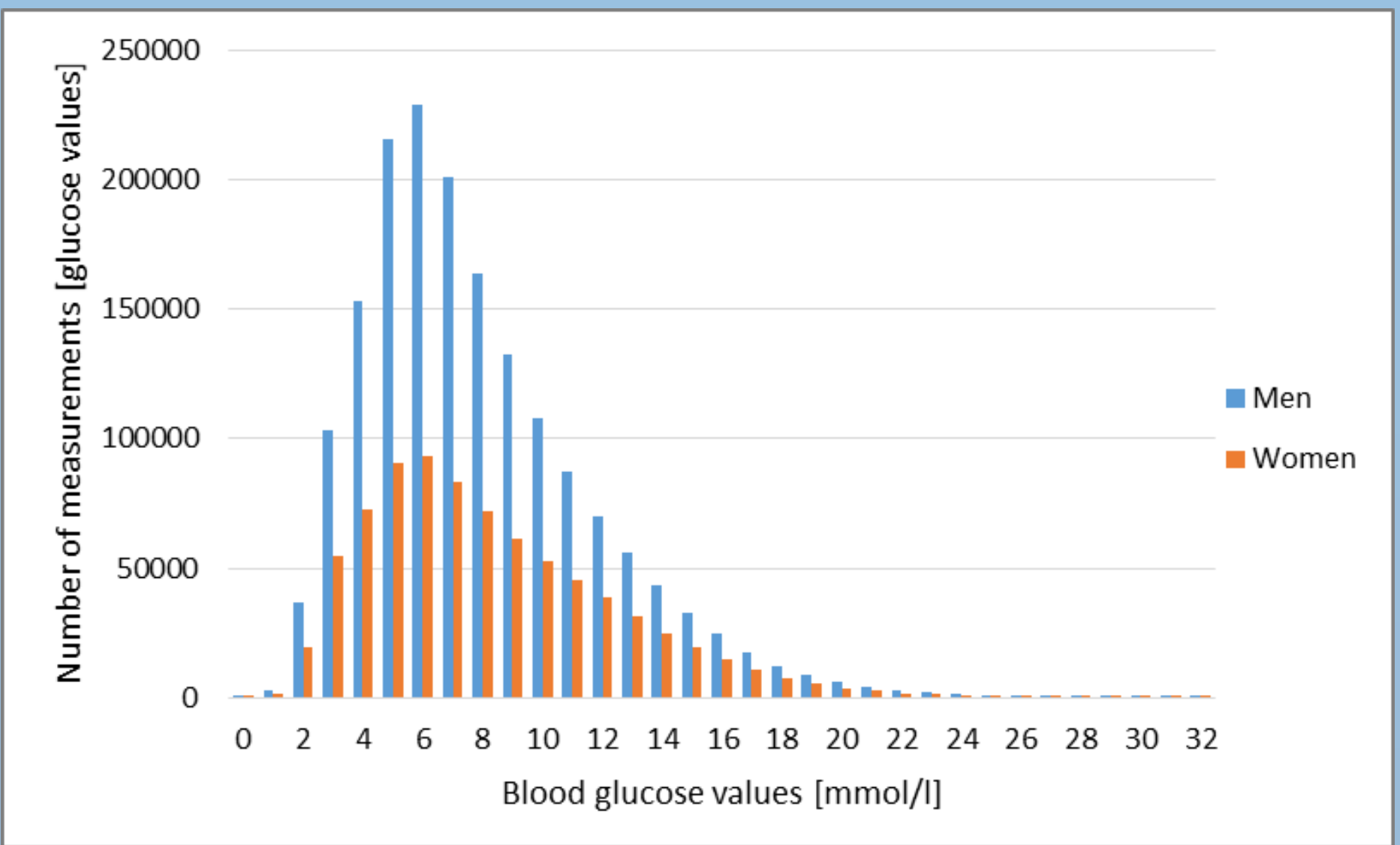

Table 3. Treatment of diabetes and SMBG

\begin{tabular}{|l|c|c|}
\hline Treatment & $\begin{array}{c}\text { Regular users } \\
\text { (n) }\end{array}$ & $\begin{array}{c}\text { Regular users } \\
\text { (\%) }\end{array}$ \\
\hline Life-style only & 157 & $6.19 \%$ \\
\hline Oral drugs & 338 & $13.33 \%$ \\
\hline Oral drugs + insulin & 354 & $13.96 \%$ \\
\hline Insulin only & 1,563 & $61.66 \%$ \\
\hline Non-insulin injectabiles & 24 & $0.95 \%$ \\
\hline Not known & 99 & $3.91 \%$ \\
\hline Total & 2,535 & $100.00 \%$ \\
\hline
\end{tabular}

Table 4. Prevalence of hypoglycemic values $(\leq 3.9 \mathrm{mmol} / \mathrm{l})$

\begin{tabular}{|c|c|c|c|c|c|c|}
\hline & \multirow{2}{*}{$\begin{array}{l}\text { Number of } \\
\text { uploaded } \\
\text { values } \\
\text { (n) }\end{array}$} & \multirow{2}{*}{$\begin{array}{l}\text { Number of } \\
\text { users } \\
\text { (n) }\end{array}$} & \multicolumn{2}{|c|}{$\begin{array}{c}\text { Number of } \\
\text { hypoglycemic values }(\geq 1)\end{array}$} & \multicolumn{2}{|c|}{$\begin{array}{l}\text { Number of users with } \\
\text { hypoglycemic values }(\geq 1)\end{array}$} \\
\hline & & & (n) & $(\%)$ & (n) & (\%) \\
\hline Women & 813,479 & 775 & 76,146 & 9.36 & 672 & 86.71 \\
\hline Men & $1,718,525$ & 1,760 & 143,451 & 8.35 & 1,380 & 78.41 \\
\hline Total & 2,532,004 & 2,535 & 219,597 & 8.67 & 2,052 & 80.95 \\
\hline
\end{tabular}

